\title{
PAGING THE ORACLE: INTERPRETATION, IDENTITY AND PERFORMANCE IN HERODOTUS' HISTORY
}

\author{
By ELTON BARKER
}

There is only one force of history that can break the reign of hatred and resentment, and expose the pretensions of tyrants, and reward the hopes of the decent and tolerant, and that is the force of human freedom. . . History has an ebb and flow of justice, but history also has a visible direction, set by liberty and the Author of Liberty. ${ }^{1}$

45 minutes from attack. ${ }^{2}$

In his early Byzantine Chronicle, Johannes Malalas fills out the figure of Cyrus, Croesus' silent antagonist in Herodotus. While Croesus is consulting the Delphic oracle, Cyrus enjoys a quite different divine audience:

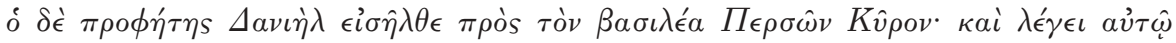

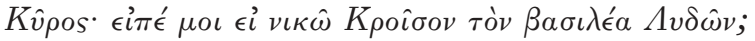

And the prophet Daniel came to the King of the Persians, Cyrus. And Cyrus says to him: 'Tell me, am I going to conquer Croesus King of the Lydians?'3

When the Christian prophet hesitates, Cyrus throws him to the lions only swiftly to repent. Daniel returns the favour by confirming that Cyrus will defeat Croesus because God breaks the 'might of kings'. Malalas' version of divine counselling clearly draws on Christian moralizing traditions; but it also flags up the confrontation between the powerful king and the word of god in Herodotus' narrativisation of Croesus' downfall. At the same time, however, it offers a radically different interpretative model. Here we don't just have a Croesus consulting the oracle and failing to comprehend it; Cyrus is told what will happen - and why - by the prophet Daniel! From Croesus (mis)reading the oracle to Cyrus receiving instruction from God,

\footnotetext{
1 Remarks by US President, George W. Bush, at his second inauguration address (Source: http:/www.whitehouse.gov/news/releases/2005/01/20050120-1.html).

2 London Evening Standard, headline, 24/09/2002. In what follows any resemblance to actual events (past or present) or real persons (living or dead) is not entirely coincidental.

3 Chronicle 6.9 (Dind. 155/157.22-3). All translations are mine.

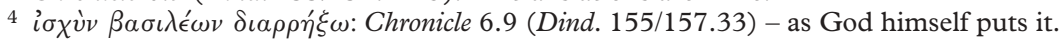


narrative dynamics have undergone a fundamental shift. It's now the gospel ...

Scholarship on Croesus testing Delphi, and on oracles more generally, has tended to focus on reconstructing the 'original' oracular texts and assessing Herodotus' role as a historian (in the modern sense of the word) in the light of how accurate his record is deemed to be. ${ }^{5}$ Notwithstanding the fact that such positivist approaches to historical writing have been challenged ${ }^{6}$ and that recent studies have been far more nuanced, ${ }^{7}$ the oracles themselves remain the focus of investigation. In tracing their 'changing representations' I want to look exclusively at how they function within Herodotus' narrative.

In this paper I examine how Herodotus uses the oracle: first, to explore the limits of power as Croesus attempts to enlist divine sanction for his expansionist project; second, to complicate a reading of his own authority in the way oracles are embedded in the narrative; third, to construct a sense of Greek identity through the performance of oracular interpretation. But before developing these points further - since whoever consults the oracle risks reading into it their own expectations - let me unpack my baggage upfront and display the tools of my enquiry.

Four issues underpin my approach. The first relates to the notorious ambiguity of the oracle, aptly summed up by Heraclitus: 'The Lord whose oracle is in Delphi neither says nor conceals: he indicates. ${ }^{8}$ Modern commentators have reframed this fundamental notion in terms of culture; for example, Tom Harrison (op. cit., p. 149):

The Ethiopians, Herodotus reports, obey their oracle to the letter and march wherever and whenever their god tells (2.29.7). How, we may wonder again, could any system of belief so inflexible be sustained? Greek oracles and prophecies, by contrast, are frequently equivocal - and so require interpretation.

5 The standard works on the Delphic oracle have establishing authenticity as their aim: H. W. Parke and D. E. W. Wormell, The Delphic Oracle (Oxford, 1956); R. Crahay, La littérature oraculaire chez Hérodote (Paris, 1956); J. Fontenrose, The Delphic Oracle: Its Responses and Operations with a Catalogue of Responses (Berkeley, 1978).

6 'We get more out of tracing changing representations than from chasing the uncatchable shadows of a real, one-time' oracle - to paraphrase Keith Hopkins, $A$ World Full of Gods: Pagans, Fews and Christians in the Roman Empire (London, 1999), 323-4, on Jesus.

${ }^{7}$ L. Maurizio, 'Delphic Oracles as Oral Performance: Authenticity and Historical Evidence', CA 16 (1997), 308-34, identifies the role of the audience in authorizing oracles; T. E. H. Harrison, Divinity and History: The Religion of Herodotus (Oxford, 2000) explores the mechanisms by which belief was sustained and reinforced; J. C. Kindt, The Delphic Oracle: A Poetics of Futures Past between History, Literature, and Religion (Cambridge PhD thesis, 2003) proposes a narratological approach that understands the use of obscure language as a strategy that 'draws the reader into the search for meaning in the story' (64). Her book is forthcoming.

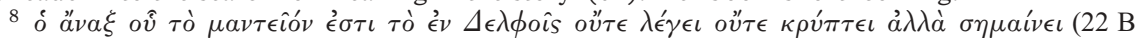
93 DK). 
Harrison implies a difference in the nature and reception of oracles: Ethiopian oracles are didactic and are followed to the letter; Greek oracles are ambiguous and demand interpretation. Robert Parker expresses that relationship slightly differently. He writes: 'arguments about the interpretation of particular oracles are so common as to suggest that they are not a by-product but an essential part of the institution's working'. ${ }^{9}$ My first point, then, is to relate Greek oracular ambiguity and polysemy to an institutional context of reception. In turn, that institutional context may best be understood in terms of the agonistic culture of ancient Greece, as implied by Giovanni Manetti's description of the divine sign as a 'mechanism which provokes interpretations, interpretations which must be tested by means of a confrontation between opposing speeches'. ${ }^{10}$ But here a note of caution should be sounded: Harrison speculates that, while misinterpretation is the rule not the exception in Herodotus, '[i]t may well, however, have been the case in practice that the majority of oracles were relatively unequivocal responses to clear questions.' ${ }^{11}$ That is to say, Herodotus is no passive conduit for oracular practice, but - along with Heraclitus - a key figure in constructing the tradition of Delphi's oracular ambiguity. Regardless of claims of 'historicity' or authenticity, the Delphic oracle in Herodotus is represented as an institution that stimulates argument over interpretation.

Leaving aside Herodotus' role in this construction of Delphi for the time being, I want to return to the different ways in which oracles are received. Lisa Maurizio has similarly distinguished between Greek and Persian approaches to oracular interpretation, but with a different emphasis:

Noisy Greek debate about the meaning of an oracle, such as we find in the story of the wooden wall oracle, is replaced by the Persians' stony silence when asked by Mardonius if they know of any relevant oracles. Afraid to risk Mardonius' displeasure, they do not reveal the oracular knowledge, which, Herodotus implies, could have saved them. ${ }^{12}$

9 R. Parker, 'Greek States and Greek Oracles', in P. A. Cartledge and F. D. Harvey (eds.), Crux: Essays Presented to G. E. M. de Ste. Croix (London, 1985), 298-326 (quotation from 301-2).

10 G. Manetti, Theories of the Sign in Classical Antiquity (Indianapolis, 1993), 34. The oracular message as open to competing interpretations: N. Thompson, Herodotus and the Origins of the Political Community: Arion's Leap (New Haven, 1996), 101, 104.

11 Harrison (n. 7), 156 (his italics).

12 Maurizio (n. 7), 328 n. 67. Cf. H. Klees, Die Eigenart des griechischen Glaubens an Orakel und Seher (Stuttgart, 1965). 
Herodotus' correction of Mardonius, according to Maurizio, 'underscores the failures of a political system in which only one man's perspective is allowed to be heard'13 - which brings me to the second subject that interests me here: power. A striking manifestation of the despot's power is the control he tries to exert over the process of signification. For example, Deborah Steiner describes how Darius, in a gesture symbolic of his majesty, literally writes himself on to and all over the landscapes he conquers: 'Darius's acquisition of kingship and subsequent empire building are . . charted through a number of inscribed stone columns and statues that proclaim his power and testify to his expanding domain. ${ }^{14}$ Given the Eastern despot's drive to author the semiotic world, Herodotus' oracle represents a key site of confrontation and struggle - as Malalas himself exploits - between kingly power and the polysemic divine word, a locus where 'truth speaks to power'. ${ }^{15}$

Many scholars have responded to that power struggle by arguing that the despot fails to grasp the full significance of the oracular message and, following on from this, that this shows the superiority of the Greek system(s) of government, in which deliberation is carried out by, and on behalf of, the citizen body as a whole. ${ }^{16}$ As Paul Cartledge has observed: 'Time and again, implicitly and explicitly, Herodotus draws a polar contrast between what we might call Greek Republican freedom and self-government and Persian oriental despotism. ${ }^{17}$ The third issue then is one of identity, a question of Greek and barbarian, of us versus them: getting the oracle right depends on who you are and where you're from.

Not all scholars have accepted the strict separation of self from other, however. For one thing, as Christopher Pelling has shown in his critique of Hartog, there are a number of examples where the self

13 Maurizio (n. 7), 328 n. 67.

14 D. T. Steiner, The Tyrant's Writ: Myths and Images of Writing in Ancient Greece (Princeton, 1994), 133.

15 E. J. M. Greenwood and P. A. Cartledge, 'Herodotus as a Critic: Truth, Fiction, Polarity', in E. J. Bakker, I. J. F. de Jong and H. van Wees (eds.), Brill's Companion to Herodotus (Leiden, 2002), 351-71 (quotation from 351).

${ }^{16}$ Dominant powers undermined: P. Payen, Les îles nomades: conquérir et résister dans l'Enquête d'Hérodote (Paris, 1997); Croesus' downfall connected to oracles: H. I. Flower, 'Herodotus and Delphic Traditions about Croesus', in M. A. Flower and M. Toher (eds.), Georgica: Greek Studies in Honour of George Cawkwell. BICS 58 (London, 1991), 57-77 (62).

17 P. A. Cartledge, The Greeks: A Portrait of Self and Others (Oxford, 2002 2 ), 76. Constructing the Other: E. Hall, Inventing the Barbarian (Oxford, 1989). Greeks versus barbarians in Herodotus: F. Hartog, The Mirror of Herodotus: The Representation of the Other in the Writing of History (Berkeley, 1988 [1980]); D. Lateiner, The Historical Method of Herodotus (Toronto, 1989), 163-86. 
appears reflected in the other and vice versa. ${ }^{18}$ Moreover, Herodotus himself is a figure on the margins. He belongs to the avant-garde of the intellectual revolution convulsing the fifth-century Greek world. ${ }^{19}$ As a native of Halicarnassus he stands on the front-line of the Greek engagement with the Other, geographically and culturally between east and west; part of what is being fought over in the history he narrates. ${ }^{20}$

With this warning against the strict separation of self and other in mind, the fourth, and final, issue I want to consider here is the position of Herodotus as a writer of prose. Much has been written about the agonistic milieu in which Herodotus was engaged. ${ }^{21}$ Building on this work Simon Goldhill, in his study of The Invention of Prose, identifies Herodotus' epic-length prose narrative as a radical departure from anything that had gone before it. ${ }^{22}$ By virtue of writing down his account in prose, Herodotus stands, therefore, on the margins in another way: as a writer in a culture that privileged the public spoken word, as a practitioner of prose in a tradition that acclaimed the poet's voice. ${ }^{23}$ In fact, we might say that no institutional context exists for what he is doing or - equally as importantly - for how that work is to be received; 'his narrative,' as Leslie Kurke has put it, 'is disembedded from a specific ritual or religious performance context. ${ }^{24}$ Given the

18 C. B. R. Pelling, 'East is East and West is West - Or Are They? National Stereotypes in Herodotus', Histos (1997). For the non-stereotyping of tyrants: V. J. Gray, 'Herodotus and Images of Tyranny: The Tyrants of Corinth', AfP 117 (1996), 361-89. L. Kurke, Coins, Bodies, Games, and Gold: The Politics of Meaning in Archaic Greece (Princeton, 1999) sees a 'struggle over the construction of tyrannic power' being played out in Herodotus' narrative (67).

19 R. Thomas, Herodotus in Context: Ethnography, Science and the Art of Persuasion (Cambridge, 2000). Cf. G. E. R. Lloyd, The Revolutions of Wisdom: Studies in the Claims and Practice of Ancient Greek Science (Berkeley, 1987).

${ }^{20}$ S. D. Goldhill, The Invention of Prose: Greece \& Rome New Surveys in the Classics no. 32 (Oxford, 2002), 11.

${ }^{21}$ Contest of voices: Greenwood and Cartledge (n. 15), 352; cf. S. D. Goldhill, The Poet's Voice (Cambridge, 1991), 167-76. Agonistic milieu: Thomas (n. 19), 249-69; M. A. Flower and J. Marincola, Herodotus: Histories Book IX (Cambridge, 2002), 4.

22 Herodotus the radical: Lateiner (n. 17), 13-51; R. L. Fowler, 'Herodotus and his Contemporaries', FHS 116 (1996), 62-87; D. Boedeker, 'Herodotus' Genre(s)', in M. Depew and D. Obbink (eds.), Matrices of Genre: Authors, Canons, and Society (Harvard, 2000), 97-114.

${ }^{23}$ Herodotus on the cusp between orality and literacy: L. Kurke, 'Charting the Poles of History: Herodotus and Thoukydides', in O. Taplin (ed.), Literature in the Greek World (Oxford, 2001), 115-37 (131); 'Herodotus' intrusive narrator must be seen in the context of late-fifthcentury oral performance culture': J. Marincola, Greek Historians: Greece E Rome New Surveys in the Classics no. 31 (Oxford, 2001), 42. For a useful warning against overplaying Herodotus' oral style: R. Thomas, Literacy and Orality in Ancient Greece (Cambridge, 1992), 102-4.

${ }^{24}$ Kurke (n. 23), 122. Kurke sees the lack of performance context as positively freeing Herodotus 'from the pressure to produce simply a celebratory narrative that serves the interests of any single community - in contrast to historical elegy or the tales of logioi and oral remembrancers'. Hugely influential - for this paper too - is the suggestion by Greg Nagy, who posits that 'the very concept of genre becomes necessary only when the occasion for a given speech-act, 
absence of an institutional context for the production and reception of an epic work of written prose, how does Herodotus get his voice heard? In short, what does authority mean to a writer of prose in a culture where literature was publicly performed - if not composed and sanctioned? ${ }^{25}$

It is anything but an innocent question. Steiner further argues that:

To write, in the landscape of Herodotus and other contemporary authors, is to enter the world of the tyrant, to set oneself on the side of the autocrat, the oppressor, the enslaver. ${ }^{26}$

Steiner here is thinking of Eastern kings and certain Greek tyrants, and limits her criticism of writing to that of the historical agents. But her label the 'landscape of Herodotus' suggestively brings to mind the situation of the author himself. Herodotus, in his practice of observing and recording, sets himself in danger of treading a similar path to the despot, who maps out the world under his possession. ${ }^{27}$ Here is the crux of the matter. Most critics readily hold the view that Herodotus is a keen supporter of freedom. ${ }^{28}$ Yet, the written text lacks the communal sanction public poetry would enjoy. How, then, does Herodotus' championing of freedom square with his authoring of an account, in which he stresses his individual effort in compiling, recording and assessing his material? Or, to put it in Steiner's terms, how does he avoid adopting the position of tyrant over his wor(l)d? ${ }^{29}$ Whereas - it is said - the cultures of the East tend towards accepting dominance with resigned passivity, ${ }^{30}$ authority in the Greek world of

that is for a poem or song, is lost' (Pindar's Homer: The Lyric Possession of an Epic Past [Baltimore, 1990], 362 n. 127, his italics).

25 ' $[\mathrm{A}] \mathrm{s}$ a freelance inquirer, Herodotus faced countless pressures. He had to establish authority for himself and, in many respects, to create the criteria according to which he wanted his work to be judged': Greenwood and Cartledge (n. 15), 352 (my italics).

${ }^{26}$ Steiner (n. 14), 128.

27 Steiner (n. 14), 142. M. R. Christ, 'Herodotean Kings and Historic Inquiry', $C A 13$ (1994), 167-202, and Thompson (n. 10), 87f., both discuss Herodotus' difference from the despot in the nature of his enquiry.

${ }_{28}$ Nicely summed up by Boedeker (n. 22), 114: 'Herodotus' new genre reflects in essential

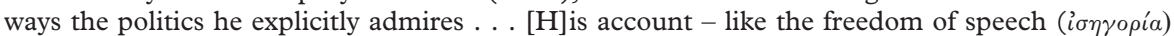
that he says made Athens successful (5.78) - gives many different voices their say, even while showing that not all speak with equal veracity and wisdom.'

${ }^{29}$ Steiner herself does not consider what implications - if any - there may be for our understanding of Herodotus as an author.

30 Thompson (n. 10), 84, characterizes the Persians as committed to the truth, and passive, in contrast to the suspicious and critical Herodotus. The Herodotean disclaimer is meant as a reminder that this opposition is a construct of the Greek imagination - and of Western critics ever since: E. Said, Orientalism (London, 1978). 
Herodotus' day is a matter of resistance, debate and negotiation. ${ }^{31}$ What kind of authority does Herodotus then have, and what might that mean for the author who records and celebrates Greek freedom from foreign oppression?

We are now in a position to return to our original question - how do the oracles function within Herodotus' narrative? - with a sharper focus to our enquiry: that is to say, how do the oracles work in relation to the problem of Herodotus authorizing his written voice? The topic of Herodotus' authority has received increasing critical attention over the past decades, ${ }^{32}$ slowly teasing out the role of the reader. ${ }^{33}$ One popular approach has been to analyse Herodotus' compositional technique and, in particular, the way in which he sets rival accounts alongside each other glossed by varying degrees of authorial scepticism. ${ }^{34}$ Critics have been tempted to read Herodotus' juxtaposition of competing voices as a form of 'dialogism', presenting his text to his reader as something akin to an 'open agora of logoi'. ${ }^{35}$ But the open texture of the narrative also works to lure in the reader, whereby 'even the explicit denial of evaluation becomes part of the rhetoric of authorization'. ${ }^{36}$ Picking up on this point, I want to propose an alternative strategy with which Herodotus gets his voice heard - without adopting the tone of the tyrant; that is, by re-presenting oracular

31 'In the world of the city-state, especially in the developed democracies, citizens had long been used to hearing alternative points of view expressed, and to adjudicating between them when they cast their votes in the law-courts and assemblies . . . The language of Herodotus shows him to be a man of his day': Fowler (n. 22), 79, 80.

32 The question of authority: C. Dewald, 'Narrative Surface and Authorial Voice in Herodotus' Histories', Arethusa 20 (1987), 147-70; J. Marincola, 'Herodotean Narrative and Narrator's Presence', Arethusa 20 (1987), 121-37; C. Darbo-Peschanski, Le Discours du particulier: Essai sur l'enquête hérodotéenne (Paris, 1987), 164-89.

33 '[T] he syntax of Herodotus' first clause is predicated on the connection made between reader and text in the absence of the author': Kurke (n. 23), 120. Cf. E. J. Bakker, 'The Making of History: Herodotus' Historiês Apodexis', in E. J. Bakker, I. J. F. de Jong and H. Van Wees (eds.), Brill's Companion to Herodotus (Leiden, 2002), 3-32.

34 On Herodotus' handling of his logoi: C. Dewald, “I didn't give my own genealogy": Herodotus and the Authorial Persona', in E. J. Bakker, I. J. F. de Jong and H. van Wees (eds.), Brill's Companion to Herodotus (Leiden, 2002), 267-89. D. Chamberlain, "We the Others": Interpretative Community and Plural Voice in Herodotus', CA 20 (2001), 5-34, distinguishes between Herodotus' singular voice - as an assertion of authority within the text (23) - and his plural voice - as a marker of his 'position as an audience to the events and characters he describes' (30).

35 Kurke (n. 18), 29. On Herodotus' 'dialogism': Dewald (n. 34), 274-7.

36 Goldhill (n. 20), 28. He continues: 'The author's refusal to pass judgement becomes a lure for the reader to adopt a critical position, to engage in the process of historie.' For similar, though more reserved, comments: Boedeker (n. 22), 113: 'All these rhetorical characteristics contribute to give the Histories its uneven, anything-but-seamless character that places the audience in the position of confidante and even collaborator with the speaker'; Dewald, (n. 34), 287: 'We are inclined to trust this voice because it is so open in its own firm declaration of tentative provisionality' (all my italics). 
ambiguity. Norma Thompson has suggested that Herodotus like Apollo 'indicates'; ${ }^{37}$ I shall explore how the act of interpretation - in this case reading - may be understood within an institutional framework of reference set out by Herodotus' appropriation of oracular discourse. ${ }^{38}$

My enquiry takes three parts. Croesus, proverbial for the man who has it all and Herodotus' starting point for his enquiry, is where I begin. By putting Croesus' consultation of the oracle at the heart of his opening account, Herodotus poses a question relating to the extent of power - can the king's rule extend over the oracle too? - and sets up an opposition between two different forms of authority: between the powerful individual who seeks to impose control over others and the Panhellenic institution that claims access to unlimited knowledge. I argue that the oracle not only challenges the king's power but also resists textual control: even as its text is written down, the way the oracle is framed escapes Croesus' - and our - comprehension. By representing oracular ambiguity Herodotus prompts scholarly debate over what we think the oracle means.

In my second section I take up the challenge to authority issued by the Pythia by examining how two examples of Delphic oracular consultations are embedded in Herodotus' narrative. Croesus' testing of the central intelligence agency is interrupted by a digression on the two predominant Greek powers that he might solicit to join his coalition of the willing against Persia, Athens and Sparta. The account about Sparta, the most powerful of the time, is structured around the interpretation of oracles. Herodotus sets up an enquiry into why the Spartans are (eventually) able to get the oracle right, while at the same time using the oracle to put the reader through a process of realising the significance of Spartan self-governance for that successful outcome. At that time, the Athenians, being held down by tyranny, do not present an attractive alliance to Croesus and are passed over. Later, however, the Athenians themselves undertake an oracular consultation, at a time when the issue of interpretation and identity is at its most urgent: when their fledgling democracy is put at risk by the Persian invasion. This, the famous 'wooden-walls' oracle that scholars have found so problematic, acquires a clearer role in Herodotus'

37 Thompson (n. 10), 14.

38 Kindt (n. 7) too understands oracular stories as reproducing ambiguity. However, whereas she places emphasis on how 'Herodotus uses Delphic oracle stories as the vehicle for statements that require a greater authority than the historian can possess' (115), I explore the construction of a (Greek) reader through the process of dissenting from such authorial claims. 
narrative once the role of the reader in performing interpretation becomes stressed. Herodotus not only reports how the oracle is brought back to the Athenian assembly, but also reproduces the struggle over its meaning for his reader. By representing the process of working through oracular ambiguity Herodotus valorizes the importance of debate at the centre of the Greek polis, and suggests a role for his text in the wider political community.

The final section takes us back to Croesus and tests the thesis that Herodotus constructs his text as an arena for thinking politically. Read as a narrative that reproduces oracular ambiguity, I suggest that Herodotus' story about Croesus' consultations performs the very resistance to oppression that it depicts when representing the boundaries of and challenges to the king's power. Readers may not only feel superior to the king, whose attempts to exert control over the world demonstrably fail when met by the oracle's ambiguous responses. They may also perform that superiority by approaching the act of interpretation with a self-reflexive, critical attitude that the king (inevitably) lacks. Readers don't just come to recognize what being Greek means; Herodotus' narrative puts them through it as a performance.

\section{Challenging authority: Croesus tests the oracles}

Herodotus begins his enquiry into why Greeks and barbarians came into conflict with Croesus, king over all the nations west of the river Halys, a figure, like Herodotus, on the margins of geography and history. $^{39}$ 'This Croesus,' Herodotus relates, 'was the first of those whom we know who subjugated some of the Greeks and took tribute from them . . . Before the rule of Croesus, all the Greeks were free. ${ }^{40}$ For Herodotus' reader Croesus represents the archetypal eastern despot who threatens the very basis of what it means to be Greek.

At the very height of his power, Herodotus explains, Croesus was 'resolved, if he could, before the Persians became powerful, to take hold of their increasing power' (1.46.1). To achieve his 'pre-emptive strike' he consults the intelligence community, oracles (1.46.3-47.1):

39 Pelling (n. 18).

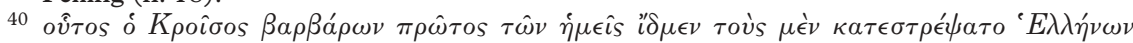

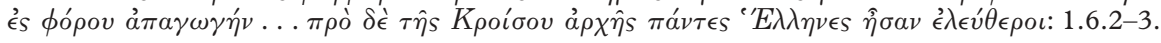




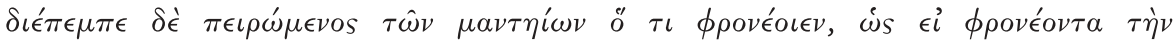

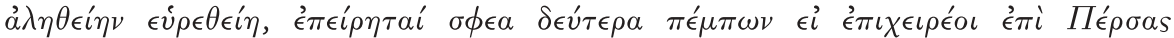
$\sigma \tau \rho \alpha \tau \epsilon \dot{v} \epsilon \sigma \theta \alpha \iota$.

He sent out [messengers] in order to test the oracles for what they thought, so that if he should discover that they knew the truth, he might send again and test them a second time, whether he should take in hand a military expedition against the Persians.

The rich and powerful Eastern king 'tests' ${ }^{41}$ the wisdom of holy sites, both - Herodotus relates - those of Greece and Libya, and including Delphi, the navel of the Greek world. The episode marks a key site in and over which the textual - and political - dynamic of knowledge and power are played out. How will the Eastern despot fare when testing such a key signifier of Greekness?

When the responses are returned (1.48.1-2),

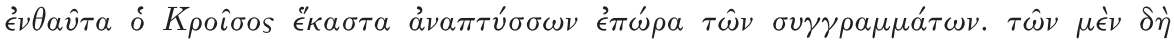

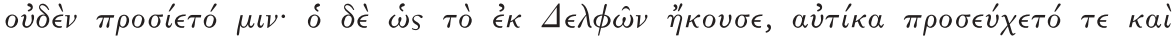

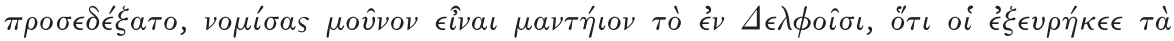

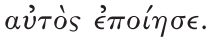

Then Croesus unfolded each and looked at what had been written. In what the others had to say nothing pleased him; but when he heard the oracle from Delphi, immediately he proclaimed it and accepted it, considering that the only oracle was the one from Delphi, because it had discovered what he had been doing.

Croesus immediately accepts the truth of the Delphic oracle. After all, he knows it's true because his question to it was to describe what he was doing. ${ }^{42}$ Not only is this oracle not predictive (for it is about what is presently being done); the enquirer already knows the answer. This is the clearest case of an agent reading into the oracle's intelligence report the interpretation he desires.

Given the fact that Croesus already knows the answer, this first oracular consultation is unique in Herodotus' narrative. For Croesus, however, it represents a paradigm that guides all his subsequent communications with the god at Delphi, including his response to the question, whether he should attack Persia (1.54.1):

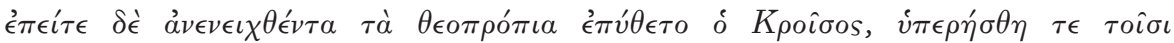

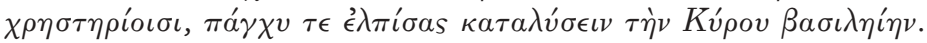

${ }^{41} \pi \epsilon \iota \rho \omega \dot{\mu} \mu \epsilon \nu$. This is a word with a good Greek tradition, used in the Odyssey of Odysseus testing people (Homer, Od. 16.305, etc.) and his bow (21.394).

${ }^{42}$ Kindt (n. 7), 99. For the Persian fascination with the truth: Thompson (n. 10), 84, $100-104$. 
When the divine responses had been brought back and Croesus had learnt of them, he was overjoyed at the oracles, completely expecting that he would destroy the kingdom of Cyrus.

As with the first oracle, Croesus is overjoyed. ${ }^{43}$ As a result, he completely expects to defeat Cyrus. He fails to realise that the answer 'a great power will be destroyed' could potentially refer to his own. His notion of exchange, offering gifts in return for knowledge, though based on traditional reciprocity and in itself pious, fails to comprehend the oracle's fatal ambiguity. ${ }^{44}$ Croesus may represent the sole voice of his people, but he cannot control the polysemic oracular word. ${ }^{45}$ Kingly power versus the divine word is no contest - and that's the problem. In the absence of debate, or indeed any institutional possibility for weighing up different options - it's just Croesus and the oracle - the oracular text remains obscure and latent with meaning.

The critical lack of reflection is signalled by the way in which the oracle first responds to the test that Croesus has set up (1.47.3):

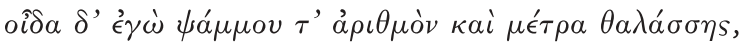

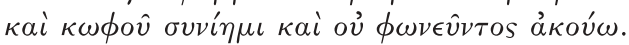

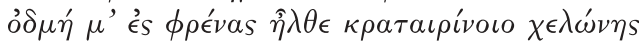

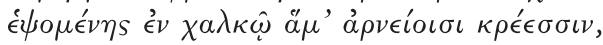

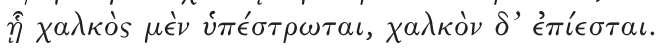

'I know the number of the sands and the measures of the sea,

And I understand the dumb, and the man who does not speak I hear.

A smell comes to my senses of a mightily armoured tortoise

Being boiled in bronze together with lamb meat,

Bronze lies underneath, and bronze lies above.'

Before supplying the answer to Croesus' test the oracle articulates its mission statement: it can count and measure what cannot be counted and measured; it can hear and understand what is unspoken. ${ }^{46}$ To

43 'Each time Croesus receives a crucial response from Delphi, he reacts to it with a feeling of (excessive) pleasure rather than careful reflection': Kindt (n. 7), 102.

44 'Kroisos presumes an unproblematic gift exchange between his dedicatory offerings to Apollo at Delphi and the god's oracular responses, only to discover too late that the two represent discrete and incommensurable "economies": Kurke (n. 18), 152.

45 'When the despot constitutes nomos, it is unstable and self-interested; when nomos is despot, the limitations provide an arena of freedom. Self-discipline and valour are encouraged by self-governing institutions': Lateiner (n. 17), 184-5.

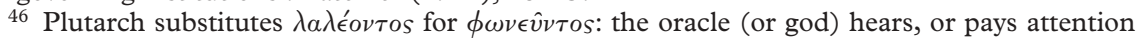

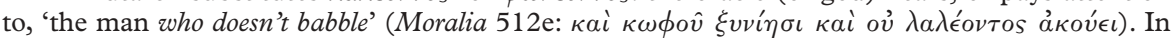
this version the oracular response appears to emphasize not so much its ability to comprehend everything (as in Herodotus) as its impatience with the testy enquirer - one way of reading this oracle consultation in Herodotus. That man is a fool who thinks he can test the oracle . . . Cf. Chamberlain (n. 34), 24. 
measure the immeasurable and comprehend the dumb signifies - if we can say it signifies any one thing - an excess of signification. It demands careful reflection and interpretation, yet Croesus pays it no heed.

The frame is superfluous to Croesus' desire to confirm what (he thinks) he knows; but it is critical for recognizing the oracle's ambiguity and appreciating its response. There is ideology to the polysemy. The (Eastern) despot fails to comprehend the different ways of reading the (Greek) hexameter verse. But it goes further than that. First, Croesus' story is plotted on a (Greek) tragic paradigm that sympathetically stages his tragedy. ${ }^{47}$ Second, Croesus is a good friend of Delphi, and Apollo does everything he can for him (1.91). Third, and more tellingly, Croesus' testing of the oracles is described in terms that could mirror Herodotus' own practice of enquiry: when Croesus had set the test for the oracles, he had commissioned his messengers to record the oracular responses in writing; when they returned with the written responses, he 'looks at what had been written down' - or, in the case of Delphi, 'when he heard it' (1.48). In that act of inscription, Croesus attempts to fix the text and supposes that by doing so he controls its meaning. He expects a simple interpretative process of matching the signs to his own expectations; but that is precisely what Herodotus' own recording of the oracle resists. For the reader, as much as Croesus, gets more, much more, than what was bargained for. Herodotus does not reveal the meaning of the oracle's frame any more than Croesus takes it into consideration. ${ }^{48}$

This is important. In this paradigmatic oracle, the reader is explicitly invited to enter into the struggle over interpretation and look beyond - or read deeper into - Croesus' staged scenario. ${ }^{49}$ One reader

47 A tragic pattern that Herodotus 'appropriates and modifies' (7) to 'define and demonstrate the distinctive methods, interests, and intentions of his own innovative discourse': C. C. Chiasson, 'Herodotus' Use of Attic Tragedy in the Lydian Logos', CA 22 (2003), 5-36, at p. 32. Cf. S. Saïd, 'Herodotus and Tragedy', in E. J. Bakker, I. J. F. de Jong and H. Van Wees (eds.), Brill's Companion to Herodotus (Leiden, 2002), 117-47.

48 D. E. W. Wormell, 'Croesus and the Delphic Oracle's Omniscience', Hermathena 97 (1963), 20-2, reads into the opening frame of the oracle the 'real' event behind Croesus' actions: he was building up a war-chest, 'and while coinage may be deaf and dumb, "money talks" (21). For Kindt (n. 7), 100, the frame reasserts the distinction between man and god after Croesus had attempted 'to communicate with Apollo in the god's own language and on the same terms' (100).

49 Both frame and answer are up for grabs, for 'this [oracle], unlike all the others, has gone undeciphered ... The response . . . is a mere restatement of Croesus' deed, and exactly what is implied in boiling lamb and a tortoise together in a cauldron remains a mystery': M. Dobson, 'Herodotus 1.47.1 and the Hymn to Hermes: A Solution to the Test Oracle', AfP 100 (1979), 349-59 (quotation from 351). 
to do just this is Malales, who significantly tags the oracle with an additional line: 'And King Croesus and his Lydians try to play me."50 That addition makes explicit what remains in Herodotus only a suggestion: namely, that the oracle perceives that Croesus has cooked something up to test it, that in effect Croesus has a hidden agenda. So, another reading might, for example, posit a connection between the oracle's representation of Croesus' act and the Homeric Hymn to Hermes. During the course of this narrative Hermes makes a lyre from a tortoise shell, which he later trades for honours from his big brother; in Herodotus Croesus makes mincemeat of the tortoise and mixes it with other meat in his cauldron. Not only is the image suggestive of Croesus damaging Apollo's goods and being deliberately deceptive, but the oracle's repeated description of the cauldron as bronze evokes the common Homeric epithet for weapons of war. Has the god seen through the smoke in Croesus' kitchen to the imperialist ambitions he is seasoning? ${ }^{51}$ Oracular meaning, which Croesus had so carefully prepared and endeavoured to keep a lid on, bubbles over. Double double toil and trouble...

It seems clear that Croesus gets the wrong end of a burning stick, because he trusts too easily and comprehensively in his own power, and fails to comprehend the possibility for alternative meaning(s). It seems equally clear that the (Greek) reader is invited to understand the (Eastern) king's downfall as a result of his misunderstanding the oracle. But that hardly empties this oracle of its meaning. By representing the paradigmatic oracle in this way, Herodotus reproduces its famed ambiguity and implicates the reader into the struggle of and over interpretation. ${ }^{52}$ This test hardly promotes a sense of superiority over the king. It certainly does not allow a complacent view of who we think we are, and what we think we are doing when we are reading. 


\section{Framing oracles: constructing the text as a site of debate}

Herodotus' representation of Croesus' test displays to the reader the difficulty of setting a text down in writing and controlling its significance. The point we noticed above all was the slipperiness of the frame that introduced Delphi's response to Croesus - a context that the royal individual singularly fails to take note of and respond to.

Given the importance of the oracle's framing it may be instructive to look at the narrative that follows, in which Croesus' impetus to extend his coalition takes the king and the narrative to Sparta and Athens, the two predominant Greek powers of Herodotus' time. At the time of asking, however, the Spartans clearly lead the way. In the narrator's embedded reporting of Spartan expansion, the oracle again plays a crucial explanatory role particularly in the way it points to the founding of Sparta's laws as the critical moment in their history - a moment the readers are invited to find for themselves. What remains implicit in this early digression on Sparta - that is, the founding of an institutional context for interpretation - is brought out by Herodotus' later account of the crisis point for the Athenians, when they consult Delphi on the eve of the Persian invasion. Herodotus not only records how they submit the oracles for debate in their assembly; he also reproduces the dialectical structure of debate in his narrative to submit the reader to a similar process of deliberation.

\section{The Spartan embedded reportage: digging for bones}

At the time of asking, the Spartans appear the ideal allies for Croesus: they too have an agenda of conquest. Their consultation meets with the following response from the Pythia (1.66.2):

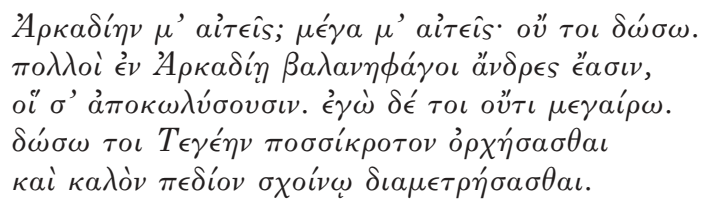

'You ask me for Arcadia? You ask me something great. No, I won't grant it.

Many are the acorn-eating men in Arcadia,

Who will hinder you. But really I don't begrudge you:

I'll give you Tegea to dance on with stamping feet

And the beautiful plain to be measured out with rope.' 
On hearing the oracle the Spartans immediately rush off to war, carrying with them chains to enslave the Tegeans, trusting - as Herodotus pointedly remarks - in a 'counterfeit oracle'. ${ }^{53}$ Having failed to analyse the oracular text properly, they return trussed up in chains of their own doing. Another case, undoubtedly, of a consultation (this time by a group of Greeks), which satisfies expectations but fails. Another case, too, in which the reader may feel superior but not perhaps without a degree of anxiety brought about by the narrator glossing the oracle as $\kappa \iota \beta \delta \eta \dot{\lambda}$ os. In what sense is the oracle 'counterfeit', a 'dodgy dossier'? On the face of it, Herodotus might seem to be criticizing Delphi's intelligence community for having deceived their Spartan overlords. ${ }^{54}$ Harrison argues, however, that the meaning need not be pejorative unless we suppose that Herodotus 'thought clarity to be a necessary or desirable characteristic in a prophecy ${ }^{55}$ - or, indeed, in any other kind of forward planning. Herodotus' glossing of the oracle then poses a series of questions: Did the oracle set out to deceive the Spartans? Or did the Spartans deceive themselves in the manner of their enquiry? Or did the oracle invite such a lack of critical reflection by its ambiguous language, especially with its concessionary, 'I don't begrudge you'? And through whose eyes do we see the oracle as being dodgy anyway, Herodotus' (as a pro-active authorial warning) or the Spartans' (in bitter hindsight)? There's no escaping our responsibility in reading the oracle. Herodotus' language confronts us with making a judgement about what we think the oracle is all about and taking responsibility for that judgement - the very thing the Spartans (had to) learn the hard way. ${ }^{56}$

'But in the time of Croesus,' Herodotus continues, 'the Spartans had gained the upper hand' (1.67.1). The reason for this is put down to the successful interpretation of an oracle. They receive this second oracle - on the whereabouts of the bones of Orestes - with much greater care (1.67.4-5). First, they acknowledge that even with the oracle 'they were no nearer to the discovery, though they were searching everywhere' (1.67.5). Second, the search for meaning is

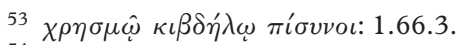

54 Flower (n. 16) glosses the use of $\kappa \iota \beta \delta \eta^{\prime} \lambda$ os at 1.75 .2 as follows: 'This is a fairly strong pejorative term suggesting that the oracle was at best unclear and probably deceptive . . cf. 1.66.3, where Herodotus criticizes the ambiguous oracle given to the Spartans about Tegea' (71, 71 n. 96 , my italics).

55 Harrison (n. 7), 152 n. 109.

56 Glossing 'counterfeit', Kurke (n. 18), 153, comments: 'The breakdown of human-divine reciprocal understanding is thus figured as a conflict of exchange systems - the Spartans assuming the "good faith economy" of gift exchange, the oracle in fact intruding like a counterfeit coin to violate the "trust" of the Homoioi.' 
described in terms of a collaborative venture. ${ }^{57}$ Herodotus relates how a certain Lichas 'brings together' the various pieces of the jigsaw to solve the puzzle. ${ }^{58}$ But this Lichas is not working alone: he is a member of the Spartan special forces who - Herodotus explains for us - are often sent out by the "common body"59 for one duty or another; when he reports his discovery, the Spartans send him back to get the bones under the pretence of exiling him (1.68.5). Lichas may use his own intelligence - and luck - to crack the code, but even so he is represented as working within a larger group. An individual acts, but his performance results from and gives service to the Spartan civic structure. The individual's performance of interpretation takes place in relation to, and on behalf of, a wider 'interpretative community'. ${ }^{60}$

More can be said, however. Herodotus himself clearly describes Lichas' thinking and explains what each line of the oracle means (1.68.3-5):

ó $\delta \dot{\epsilon} \epsilon$ '́v

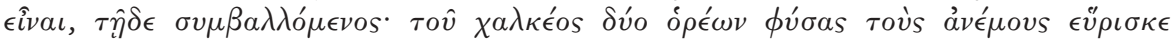

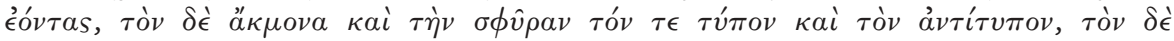

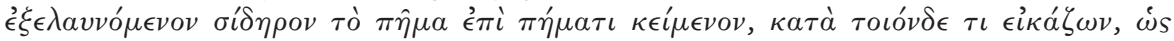

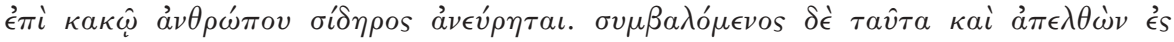

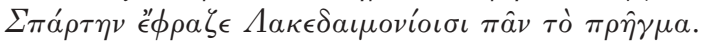

Taking in mind what was said, [Lichas] made the connection with the oracle that this was Orestes, making the connection in this way: he discovered that the 'winds' were the blacksmith's two pairs of bellows; the 'smiting and counter-smiting' the hammer and anvil; and the 'woe on woe' was the drawn-out iron, conjecturing in this way that iron has been discovered to be an evil for mankind. Having made these connections, he went back to Sparta where he declared the whole thing to the Spartans.

The reader is led through a process of 'bringing together' $(\sigma v \mu \beta a ́ \lambda \lambda \epsilon \sigma \theta \alpha \iota)$ the different parts of the jigsaw for himself. This is

\footnotetext{
${ }^{57}$ Kurke (n. 18), 154, suggests that 'the oracle seems to align itself with civic structures'. Contrast Kindt (n. 7), 106-7, who emphasizes Lichas' isolation.

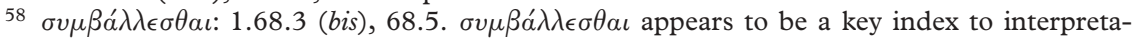
tion: applied by Herodotus to his own reasoning (at 2.33.2, 112.2; 4.15.1, 45.2, 87.2; 6.80; 7.24, $184.1,187.2 ; 8.30 .1)$, and to the reasoning of others $(2.33 .2 ; 3.68 .2 ; 5.1 .3 ; 6.107 .2($ bis $), 108.1$; $7.10,142.2,189.2 ; 8.94 .2)$. See further the discussion of the 'wooden-walls' oracle below.

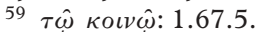

60 The phrase is culled from Stanley Fish, Is there a Text in this Class? (Cambridge, Mass., 1980). He applies it, however, to academic 'schools' of thought and their power to constitute the objectives by which texts are judged (338), whereas I wish to denote the institutional framework within which the agent works, a context which Herodotus represents and, to a certain extent, reproduces in his text. Chamberlain (n. 34) similarly argues against the view that Herodotus' first person plural statements should be read as appealing to a ready-made 'limited community of like-minded critics' (5).
} 
significant. In the case of the paradigmatic oracle given to Croesus, Herodotus' text had reproduced something of the oracle's ambiguity to point up not only the inadequacy of the king's response, but also the lack of any opportunity within the institution of autocracy itself to respond well. On this occasion Herodotus very carefully guides his readers through the analysis of the oracle's text, so very carefully in fact as to render the act of interpretation transparent. ${ }^{61}$ Lichas goes back to Sparta and 'declares the whole thing' to his community; the narrative mimics that translation of the oracle by 'declaring the whole thing' to a community of readers. Herodotus not only represents Lichas' interpretation as taking place vis-à-vis a civic context; by placing his readers on a par with Lichas' Spartans, Herodotus constructs his text as a space that might also be regarded as civic, as also bringing power to the people. His very gesture of openness, then, is a lure to elicit authority for his text.

This oracle, the last of a series given to the Spartans and the first within Herodotus' enquiry to be interpreted correctly, indicates the single agent's role within a recognizable civic structure. To what do the Spartans owe this common framework? Herodotus' account of Spartan hegemony (the feature that most attracts the like-minded Croesus) begins with a curious oracle given to Lycurgus, Sparta's founding father (1.65.2):

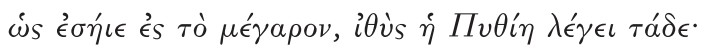

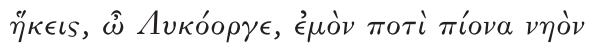

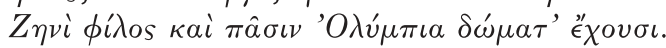

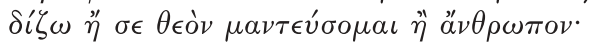

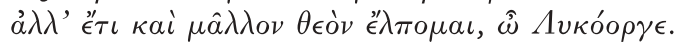

When Lycurgus went into the hall, the Pythia immediately said these things:

'You come, Lycurgus, to my rich temple,

Dear to Zeus and to all who dwell in the house of Olympus.

I am at a loss whether to prophesy you as a god or a man:

But I expect you are more of a god, Lycurgus.'

What strikes most readers of this oracle is its lack of obvious purpose: 'There is no message, if the four verses that Herodotus quotes are the whole response. ${ }^{92}$ The absence of a message results from the absence

${ }^{61}$ Kindt (n. 7), 106, notes the 'strikingly elaborate' description of Lichas' train of thought, an account she assigns to the 'voice of the omniscient narrator'. She passes over, however, the question of why we should get such an account here.

${ }^{62}$ Fontenrose (n. 5), 116 (my italics). He continues: 'It may well be that its lack of message caused someone to add the two hexameters that Diodorus quotes; but they amount to no more 
of a context, as the narrative imitates the Pythia's act of spontaneity: the oracle appears spontaneously in the text with neither an introduction nor any indication of its relevance. Not knowing why the consultation was made in the first place or why the Pythia should answer in these terms - it appears more of a statement than an oracle - invites speculation and throws weight on Herodotus' subsequent narration of the Spartans' nomoi (1.65.4):

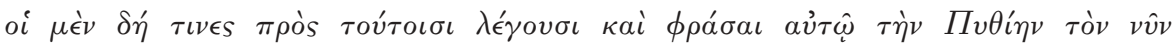

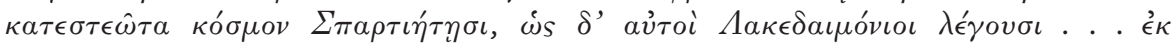

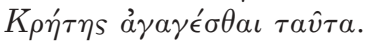

Some say that the priestess also declared to him the government that is now established for the Spartans; but the Spartans themselves say that Lycurgus brought these changes from Crete.

Some interpreters, Herodotus explains, connect Lycurgus' oracular consultation to his subsequent establishment of Sparta's institutional framework. (Is this why the oracle addresses Lycurgus as a god, because he - so the story goes - laid down the law for the Spartans?) The implicit basis of Lichas' later, successful interpretation of the Orestes oracle is the institutional framework within which he operates; here Herodotus invites his readers to relate its foundation to an oracle. The process that readers go through if they choose to make that move is significant: in the very exercise of interpretation they realise the importance of the institutional setting for getting interpretation right. Though the act of reading is in and of itself individual, Herodotus' readers may perform that act in relation to, or even as part of, a civic group. Reading is not (yet) conceived of, or represented as, a solitary practice - as the example of Lichas demonstrates.

The way Herodotus embeds in his Croesus narrative the digression about the Spartans' successful interpretation of oracles encourages deeper reading and a process of 'bringing together' different signs. My suggestion has been to read the Spartan oracles together and to relate the successful working out of the Orestes oracle to the foundation of an institutional framework that makes such an interpretative process

than a statement that Apollo will give Sparta the finest constitution of any city's.' Diodorus Siculus' two lines of explanation that give Lycurgus' consultation and the subsequent oracle

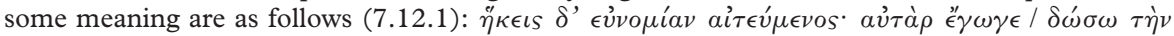

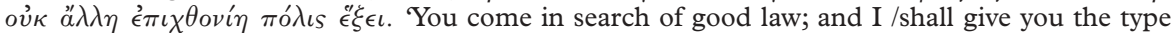
that no other city on this earth will have.' This gloss suggests the importance of the Spartans' nomoi for thinking about the oracle along the lines that I argue here. 
possible. ${ }^{63}$ Moreover, the impromptu oracle prompts a response that realizes the potential within the narrative for reading as a member of a group of free citizens. The act of reading is thus framed by an interpretative community. At the same time, however, Herodotus places emphasis on the individual's responsibility for getting interpretation right. His narrative both represents and supplants the civic context of interpretation.

\section{The Athenian debate: dismantling wooden-walls}

I have just suggested that responding to the oracle invites a reading that both is informed by, and seeks to replace, a public institutional context. To follow up this claim, I fast forward to the crisis point - the war between Greeks and barbarians. On the eve of the Persian invasion of Attica, an invasion which puts at stake the very existence of the Athenian polis and, more generally, threatens the very idea of a Greek identity, the Athenians consult Delphi: should they stay or should they go? The oracle that the Athenians get in reply - containing the notorious lines about the 'wooden-wall' - has attracted enormous interest. Various attempts have aimed at reconstructing its original text, date, composition and reception, and at assessing its 'historical' role in the Greek resistance to the Persian invasion. ${ }^{64}$ For my purposes, it affords an opportunity not only to compare the respective practices in consulting oracles of Croesus and the Athenians, but also to show more explicitly the performative aspect of reading oracles within Herodotus' narrative.

Faced by the threat of the Persian invasion, the Athenians go to Delphi to consult the oracle. The response is so gloomy that on the advice of a certain Delphian official they ask for another (7.141). Though barely more cheery, this oracle about Salamis and woodenwalls is accepted and taken back to Athens. There are two features about this episode I want to consider.

First, there are two oracles. Though the first oracle is often passed over with little or no comment, Herodotus sets up the oracles to be read together $(7.139 .6-140.1): 65$

${ }^{63}$ A point that gains emphasis when we return to Croesus' story to find him still a solitary reader and still reading wrongly.

${ }^{64}$ Searching for authenticity: e.g. N. Robertson, 'The True Meaning of the "Wooden Wall"', CP 82 (1987), 1-20. For a critique of this and of other attempts: Maurizio (n. 7), 308, 329-30.

65 Harrison (n. 7), 151-2. 


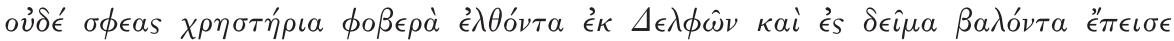

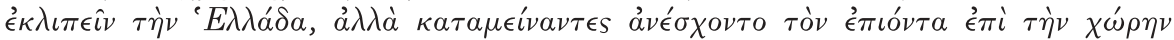

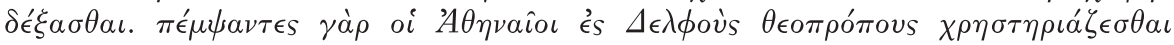

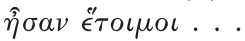

Nor did the fearful oracles that came from Delphi and threw them into fear cause them to flee Greece, but standing firm they resolved to meet the invader of their country. For the Athenians had sent messengers to Delphi and were ready to receive an oracle...

The fact that the initial oracle is not explicitly deliberated on by the Athenians may mean it slips from view. But Herodotus' grouping of the oracles together clearly invites the reader to consider the relationship between the two. And, because the first receives no further elaboration or elucidation, the narrative places an onus on the readers to work it out for themselves.

One recent scholar to have taken up the challenge is Lisa Maurizio. She suggests that the first oracle frames interpretation of the second. In the first, the language of the body dominates, representing Athens as a living being: answering the second oracle then means determining what Athens stands for, 'its population or its physical territory'. As she puts it, 'These two oracles reflect a crisis in the very definition of Athens as a city. ${ }^{, 66}$ The question of identity, however, is not, I suggest, limited to the Athenians in the text. A similar crisis is set before the reader.

Let me explain by exploring in greater depth a second important point: that is, Herodotus' structuring of this account. We have already noted the juxtaposition of two oracles, which invites comparison and deliberation. That gesture is brought out by the narrative: Herodotus relates how the oracle is written down by the ambassadors and taken to the people for consideration. ${ }^{67}$ (Nothing could be further from Croesus' solipsistic, emotional and immediate response to the oracular text.) What is particularly interesting for our argument is the way in which Herodotus subsequently represents the assembly. His narrative telescopes the discussion on to the problem of interpretation. In particular, he articulates a struggle over how to understand the phrase 'wooden-walls' - either literally as the wall surrounding the Acropolis, or more metaphorically as a fleet of ships. The official interpreters

\footnotetext{
${ }^{66}$ Maurizio (n. 7), 331. She continues, "Whether they reflect particular historical details and can be mined for them, as many scholars have tried to do, is unlikely.'

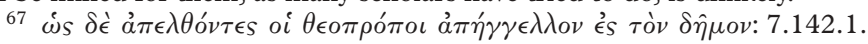


'clung to the letter of the oracle', ${ }^{68}$ insisting on a literal translation that replays Croesus' earlier obsession with sticking to what was written. Their inability to make the mental leap beyond that is brought out by Themistocles' criticism: he was arguing that they were not 'putting together rightly' ${ }^{\prime 9}$ the meaning. In an open debate over how to interpret, as much as what to interpret, Themistocles provides a more convincing case for his audience than the professionals can manage. Reasoned argument overcomes the expertise of a closed group. This is arguably the clearest example of the importance - and success - of debate in Herodotus. ${ }^{70}$

But there is an additional point to bring to bear on our analysis that is suggested by the way in which the narrator sets up the debate (7.142.1):

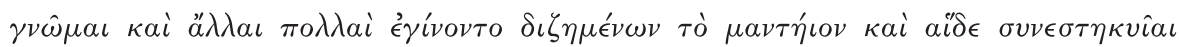
$\mu a ́ \lambda_{\iota} \sigma \tau \alpha$.

There were many alternative opinions of those enquiring into the oracle's meaning, and those that stood together most of all were the following.

By drawing attention to the 'many other opinions' that were being put forward in the assembly, before narrowing the focus to the two he records, Herodotus displays a self-consciousness in his structuring of this episode of a degree normally ascribed to Thucydides. ${ }^{71}$ What is more, this frame involves the reader in the ensuing debate. The issue depends on how we translate aí $\delta \epsilon \sigma v \epsilon \sigma \tau \eta \kappa v i a \iota \mu \alpha^{\prime} \lambda \iota \tau \alpha$. This could simply indicate 'those opinions that held together the best', those that were the 'most convincing'. ${ }^{72}$ Indeed, in what follows Herodotus describes the two opinions that best accord with the process of 'interpreting' ( $\sigma v \mu \beta a ́ \lambda \lambda \epsilon \sigma \theta \alpha \iota)$, a label that is applied to the oracle interpreters even as Themistocles rejects their interpretation. ${ }^{73}$ Yet,

68 W. W. How and J. Wells, A Commentary on Herodotus (Oxford, 1912), 184 n. 142.2.

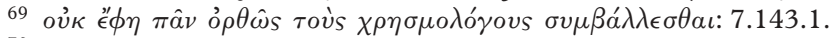

70 Democratic debate contesting notions of priestly authority: M. Detienne, The Masters of Truth in Archaic Greece (New York, 1996 [1967]), 89-106. Herodotus goes on to describe the pay-back for those who insist on the literal meaning of the 'wooden-walls': still believing that the wooden-walls of the Acropolis would save them (8.51.2), all are killed when the Persians storm the barricades (8.53.2).

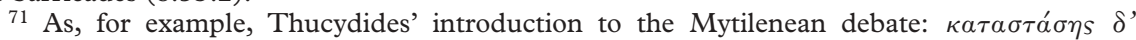

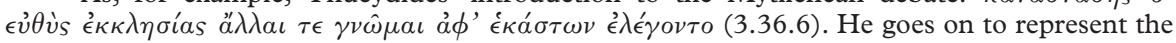
assembly in terms of a contest between Cleon and Diodotus.

72 As suggested to me by Christopher Pelling.

${ }^{73}$ Herodotus denotes the 'interpretation' of the oracle experts ( $\sigma v v \in \beta a ́ \lambda \lambda$ ' Themistocles contests that 'interpretation' ( $\sigma v \mu \beta a ́ \lambda \lambda \epsilon \sigma \theta \alpha \iota: 7.143 .1)$ and argues for a better 'interpretation' ( $\sigma v \lambda \lambda \alpha \mu \beta \alpha ́ v o v \tau \iota: 7.143 .2)$. 
that is not how it is usually taken, and this must, I think, relate to the account that follows, in which Herodotus investigates the wrangle over the oracle's disputed lines. Thus, most scholars have taken ai $\delta \epsilon$

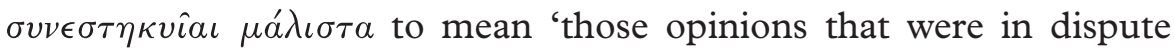
most of all', those that were 'most opposed'. ${ }^{74}$ If this is right, and Herodotus is indicating his selection of the two most opposed arguments of the day, such a gesture would render his account even more strikingly 'Thucydidean'. But, more importantly, his framing of the debate invites such a reading. It sets the readers up to perform for themselves the process of debate.

It is significant, for example, that scholars who talk about the capacity of debate to rationalize the divine word use this oracle. Manetti, for example, describes how:

The discrete binary logic of the dialectic alternative gives way to the continuum of the gradated logic of the preferable. It could well be that the discussion so far has caused us to lose sight for a moment of the fact that the object in debate is a prophecy of Apollo. This is significant, for the logic applied to the interpretation of the divinatory response is precisely the same as that which governs political assemblies. ${ }^{75}$

Here Manetti equates the way of responding to oracles with the notion of debate that is conducted in the assembly. But in fact it is Herodotus who encourages exactly such an interpretative process by the way in which he has structured the episode according to alternative, even contrary, arguments. It is Herodotus who renders the interpretation of the divinatory response the same as that which governs political assemblies.

This is important. Jean-Pierre Vernant has also used the woodenwall oracle as an example of dialectical logic; ${ }^{76}$ but the general thrust of his analysis stresses the difference of oracular interpretation from the 'public and conflictual debate' performed in the Greek polis:

From this point of view, it is noteworthy that in classical Greece we find oracular activity concentrated for the most part around the great sanctuaries, whose Panhellenic character relegates them to the margins of the city. They are outside the institutional framework that defines the civic community and that, with free discussion and the right

\footnotetext{
74 'Amongst the various opinions which were expressed there were two mutually exclusive interpretations': A. de Sélincourt, Herodotus Histories (London, 1996). Cf. How and Wells (n. 68), 183 n. 142.1; R. W. Macan, Herodotus (London, 1908), 191 n. 142.1; E. von Heinrich Stein, Herodotus (Berlin, 1963), 137 n. 142.1.

75 Manetti (n. 10), 34 (my italics).

${ }^{76}$ J.-P. Vernant, 'The Individual within the City State', in F. I. Zeitlin (ed.), Mortals and Immortals: Collected Essays of F-P Vernant (Princeton, 1991), 303-17 (311).
} 
to vote, makes each of its members a fully participating citizen in all the processes of decision concerning public affairs. ${ }^{77}$

Bringing this perspective to bear on our discussion, I want to sum up Herodotus' oracles to Athens by making two points. First, he firmly locates them within the context of the assembly. That is to say, far from being on the margins Herodotus relocates the oracle of Delphi at the centre of the institutional framework that defines the civic community: oracular interpretation is a matter of debate for the group at large. Second, and following on from this move, Herodotus uses oracular consultation to construct his text as an arena of interpretation that may stand on a par with the assembly itself. In other words, Herodotus places both the oracle and his text at the centre of the polis. Herodotus' enquiry, which - by virtue of being written - would normatively stand outside the institutional framework of the polis, by means of his re-presentation of oracles invites a reader to participate fully in the processes of decision-making. It is not just the oracle that is the site of struggle and conflict; Herodotus' text itself becomes the battleground over which the readers fight for control of meaning and for their own identity.

The way in which Herodotus structures his account of this double oracular consultation and subsequent debate reproduces a resistance to the truth and authority of the written text, a resistance such as that which Herodotus the narrator had urged when praising the Athenians for their reaction to the oracles. ${ }^{78}$ The issue is greater than how Herodotus' narrative invites its readers 'to be analysed and interpreted themselves' $;^{79}$ that process of self-reflection - appropriated from the context of oracular interpretation - is a political one. 'The difference between the Herodotus and the Persian approach is one of suspicion and uncertainty as opposed to passivity. ${ }^{, 80}$ Representing the oracle is not neutral but fundamental to a reading of his text. Fighting - reading - for Greece . . .

To explore some of the consequences of this reading, I follow Croesus and consult the oracle one last time.

77 Vernant (n. 76), 306 (my italics).

78 'But standing firm they were resolved to meet the invader of their country' (7.139). Herodotus' narratorial comment leads directly in to an analysis of the pair of oracles, as he continues: 'For the Athenians had sent messengers to Delphi' (7.140.1). For Greek resistance: Thompson (n. 10), 104; Harrison (n. 7), 149-52. Cf. Manetti (n. 10), 33.

79 Kindt (n. 7), 65.

80 Thompson (n. 10), 84; cf. 95. 


\section{Performing enquiry: Croesus' final consultation}

In the first section I argued that Herodotus represents Delphi's oracular response in such a way that he reproduces its ambiguity and displays the difficulty of controlling the divine word even once it has been written down. In the second section I explored two examples that indicate the importance of Herodotus' framing of the Delphic oracle and that suggest he constructs his text as an arena of interpretation on a par with, and in place of, the public institutional space of the assembly. In this final section I explore this last claim further by reflecting on how Herodotus begins and ends Croesus' oracular consultations.

In the first section I noted how Croesus receives oracular responses to his test in the following manner (1.48.1-2):

Then Croesus unfolded each and looked at what had been written. In what the others had to say nothing pleased him; but when he heard the oracle from Delphi, immediately he proclaimed it and accepted it, considering that the only oracle was the one from Delphi, because it had discovered what he had been doing.

Thus Delphi is extolled by Croesus as the oracle. Yet, in the very next paragraph Herodotus continues (1.49.1):

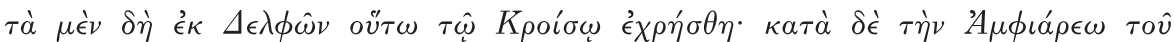

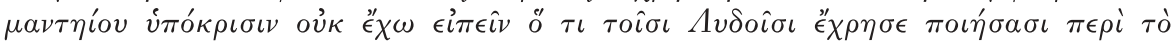

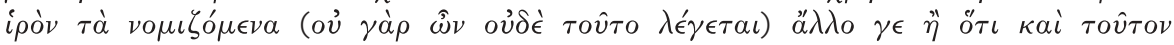

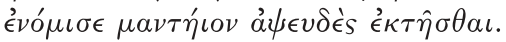

Such was the oracle from Delphi to Croesus. As to the answer from the oracle of Amphiareus, I am not able to say what it said to the Lydians once they had followed the temple custom (for this is not said), other than for the fact that Croesus considered that he had acquired in this one too an oracle that did not lie.

Having just proclaimed Delphi as the only oracle, Croesus according to Herodotus - also thought that the oracle of Amphiareus was 'not lying'. In fact, throughout this episode Croesus consults and receives answers from both Delphi and Amphiareus (1.53.1, 53.3, $54.1)$ - though it is always Delphi that is kept in focus. How can Delphi be acclaimed as the only true oracle in one breath, when in the next the truthfulness of a rival site is conceded? ${ }^{81}$ Is it Croesus who is

81 'One might suppose that the unsuccessful replies had been hushed up, and the incident forgotten as quickly as possible by the other oracle centres. But Herodotus himself found that the oracle of Amphiaraus had been honoured, like that of Delphi . . . Herodotus himself was 
inconsistent, who readily accepts Delphi as the one true oracle before he has all the evidence in front of him? Or is the problem one of the narrator's doing who, since he was 'not able to say' what its response was, adds grudgingly that it was also true? And does this in turn reveal a critical process of selectivity in which the historian privileges Delphi (presumably because this is the oracle to which he has access)? ${ }^{82}$ Or is it rather the reader's problem for failing to notice the author's clear markers of uncertainty in his account, tempted perhaps by the prospect of Delphi's success in delivering the Eastern despot's come-uppance? Frustrating a facile reading of his text, his account of the oracular responses reproduces something of their ambiguity. The oracular texts may suffer from a lack of debate when written down and shown to Croesus; but Herodotus constructs exactly such an interpretative crisis for his reader. In his act of inscription, of writing down the logoi that he has collected, Herodotus poses a series of questions concerning not only issues of composition but also the reader's interpretation of and performance within that narrative.

The Lydios logos ends with Croesus visiting Delphi one last time. $\mathrm{He}$ wants to know why his previous consultations got his fingers burnt and much more besides. On this basis alone it is already a kind of meta-consultation, an enquiry into how and why his previous enquiry had gone wrong. Apollo's response continues in the same vein $(1.91 .1,4)$ :

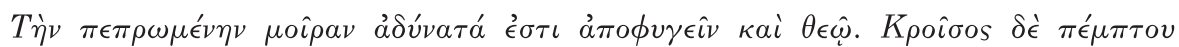

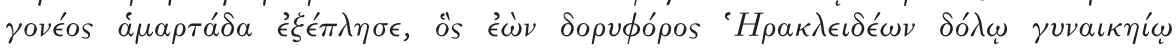

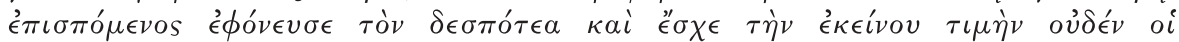

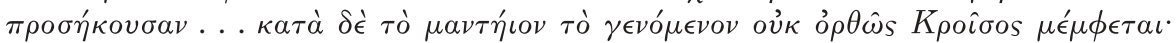

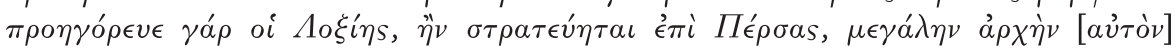
$\kappa \alpha \tau \alpha \lambda v_{\sigma} \epsilon \iota$.

'It is not possible to escape the appointed fate, even for a god: Croesus has fulfilled the error of his fifth-generation ancestor, who though a guard of the Heracleidae was led by feminine guile to murder his master and take the honour of that man which was not fitting for him . . . As to the oracle that was given, Croesus does not rightly blame it. For Loxias declared to him that, should he attack Persia, he would destroy a great power...'

aware of the inconsistency, and appends the oracle centre of Amphiaraus to that of Delphi in a couple of places in his narrative. But it is evident that it does not fit': Parke and Wormell (n. 5), 131-2 (my italics).

82 Before recording Delphi's response, Herodotus admits, 'What the rest of the oracles

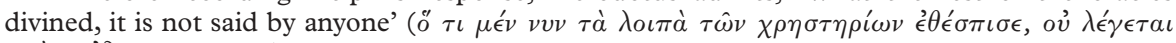

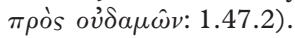


Croesus had failed to ask the proper questions - and, anyway, it was his fate. This affirms our reading of Croesus' consultations ${ }^{83}-$ but is the pay-back as transparent as all that? Of course Croesus gets it wrong, because he failed to ask the appropriate follow-up questions. But if he had done, would he have been able to change things when it was his fate? ${ }^{84}$ When all is said and done, whether or not Croesus asks which power he will destroy is beside the point, since he fulfils the error of his ancestor. And yet, Croesus does in fact lose his empire because he failed to interpret the oracle correctly. Damned if you do, damned if you don't ... .

Consulting the oracle has a twist in the tale for the reader - not only Croesus. (That is the danger of approaching the oracle, with an answer already in mind.) Herodotus invites us throughout this narrative to dissent from Croesus' reading of the oracle and to see this as a fault of an institutional system that privileges the rule of one man. But, in the end, the reader is asked to remember the first oracle that Herodotus had narrated, the one which had concluded his opening account of Gyges (1.13.2):

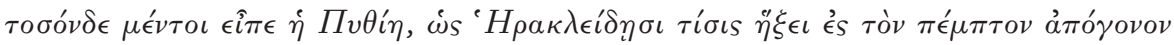

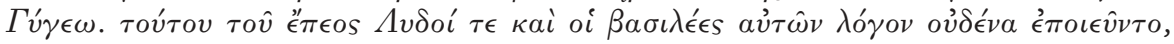
$\pi \rho i \nu \delta \grave{\eta} \epsilon \pi \epsilon \tau \epsilon \lambda \epsilon^{\prime} \sigma \theta \eta$.

The Pythia however said this: that vengeance for the Heracleidae would visit in the fifth generation of Gyges. Of this utterance the Lydians and their kings took no account, until it was fulfilled...

Herodotus expressly warns us that 'no-one took account of' this oracle. Having read through the subsequent narrative of Croesus' downfall, the reader could be forgiven for losing sight of this point only to be reminded of it at the end by Apollo. Herodotus' narrative

83 'It skilfully lists different motifs of and reasons for Croesus' fall. It also closes the cycle of prediction and fulfilment stated at the beginning of the Croesus Logos with the Delphic sanction of Gyges' kingship': Kindt (n. 7), 110. For Kindt, 'The story of Croesus' fall can . . . be read as a "prophecy" of what we will find happening time and time again in the Histories. It is the story of a ruler who, at the beginning of the logos, is at the peak of his power. Croesus, however, seems to lack a sense of balance and proportion. Without a sound point of reference for his judgements he gradually transgresses the limits of his power . . . Such hybris, Herodotus wants us to believe, must necessarily result in failure.' (114, 115).

${ }^{84}$ Goldhill (n. 20), 25, notes in passing: '[N] ow the historian has the oracle reveal that on the one hand the crime of Croesus' ancestor demands expiation and, on the other, that Croesus' own misinterpretation is the problem (as if Croesus could have avoided such expiation if he had but asked a follow-up question).' Pelling also raises this discrepancy - and what that might mean for the reader - in his paper 'Educating Croesus' (forthcoming). 
on Croesus' test is not just about the failure of the king to get the oracle right; it's also a test of the reader's reading ability.

In the final analysis the politics of polysemy is turned back on the reader. We are invited to look at the episode beyond the narrow frame of its specific occurrence and take into consideration both its beginning and end - a perspective that we might now call 'historical'. ${ }^{85}$ Furthermore, it is a perspective that is facilitated by possessing a written text that can be read and re-read, and (re-)read in different ways at different times . . . The over-determination of Croesus' fall pushes the reader to think about, and think with, how to enquire into and interpret past events. In this way, the genre Herodotus creates can play a critical role in helping to inform and shape the politics of the wider (Greek) world. ${ }^{86}$

\section{Conclusion: Operation reading for freedom}

The oracle is notoriously polysemic. I offer two brief points for consideration.

First, Herodotus' location of the oracle at the heart of his first logos affords an opportunity to explore the limitations of human authority, notably of the powerful Eastern king. The despot, acting by himself for himself, fails to comprehend the potential for polysemy. But there is little sense of triumphalism or superiority. ${ }^{87}$ Readers are not only confronted by the different approaches to receiving oracles; they are also invited to reflect on what lies as the root causes of those differences. The Spartans appear capable of responding to oracular ambiguity because of their constitutional arrangement. Later on, in real and narrative time, the importance of an institutional framework for interpretation is made explicit when Herodotus has the Athenians literally bring the oracle back to discuss in their assembly and make the correct interpretation (in spite of what the official oracle interpreters say) because of debate.

But this is only half the story. Second, and following on from this, the ways in which Herodotus represents Croesus' oracular consultations reproduce the testing for, and turn the enquiry back on to, the

${ }^{85}$ Looking to the end: Greenwood and Cartledge (n. 15), 351. The classic statement is in Herodotus' narrative itself, Solon's advice to Croesus (1.32.9).

86 'No figure is more significant than Herodotus in this development of Greek self-representation': Goldhill (n. 20), 16.

${ }^{87}$ Not enough anyway to satisfy Plutarch: de Malignitate, Mor. 856c. 
reader. By appropriating the Panhellenic institution (and authority) of the Delphic oracle, Herodotus sets up his narrative in competition with the public institutions that structure debate and enable communal involvement in the polis. Herodotus then not only allows us an insight into the failure of the all powerful individual when confronted by the polysemic divine word; we are invited to perform that superiority over the king and enact our difference as independent citizens by reading.

Croesus' testing of the oracle is therefore performative: readers may also face (up to) the oracle's ambiguity and, by testing it, understand and enact their difference from all despots and despotic regimes, eastern or otherwise ... In this self-conscious resistance to authority, including - or especially - that of Herodotus himself, even reading can be an activity associated with performing as an independent free-thinking citizen. By seeing reading as a separate exercise from making political judgement, by emptying history of the struggle of enquiry, by surrendering responsibility for judgement to an Author, we risk losing that liberty we so cherish. ${ }^{88}$

${ }^{88}$ I have enjoyed many oracular consultations with friends and colleagues, above all Elizabeth Irwin, Julia Kindt, Kyriaki Konstantinidou, Robin Osborne, Christopher Pelling, and Rob Tordoff; mistaken responses are my own. I am indebted to Roger Brock, who first displayed the wonders of Herodotus' enquiry to me, and David Hahm, with whom I first experienced the pleasure of reading Herodotus in Greek. 